\title{
The Study of Water Quantity and Quality (Case Study: Gajahwong Watershed)
}

\author{
Sukma Sayono Putro \\ Division of Administration, Center for Construction Services Region V, Banjarmasin, INDONESIA \\ sukma.saputro@gmail.com
}

\begin{abstract}
Gajahwong River is one of the nine rivers in the Special Region of Yogyakarta Province. During dry season, its water quantity has been decreasing so the water flow is insufficient to dilute the pollutant from sewage and affecting the water quality. Some pollutant parameters that have exceeded the quality standard in the Gajahwong river are including BOD, COD, TSS, phosphates, and total coliform. The study is expected to show the relationship between the water quantity and water pollution parameters and how to mitigate it. Water availability at the river was analyzed by using Mock model and the result was presented in flow duration curve. Climate data including rainfall for 12 years period from 2001 to 2012 were collected. The condition of river water quality was analyzed using Pollution Index Method. Results show that dependable flow at $80 \%$ probability was $0.80 \mathrm{~m}^{3} / \mathrm{s}$. Water quality conditions in the Gajahwong River from upstream to downstream have declined at moderately polluted level. During 2007 to 2012 the level of TDS, TSS, DO, COD, detergents, oils, and fats, and fecal coliform has decreased. The concentration of water quality parameters was increased like BOD, phosphate, and total coliform that causing polluted water. The concentration of TSS, BOD, COD, phosphates, detergents, oils and fats, fecal coliform, and total coliform exceeds the threshold of water quality standards class II.
\end{abstract}

Keywords: water quantity, Mock model, water quality, pollution index

\section{INTRODUCTION}

The availability of water in the Gajahwong watershed in 2012 was deficit in some areas due to droughts that cause reduction of discharge up to $40 \%$. In addition, the water quality in the Gajahwong watershed has decreased due to sewage contamination (BLH Provinsi Daerah Istimewa Yogyakarta, 2012).

A variety of land use activities in the Gajahwong watershed area such as settlements, agriculture, and industry have affected water quality. Some pollutant parameters that have exceeded the water quality standard in the Gajahwong watershed are Total Suspended Solid (TSS), Biochemical Oxygen Demand (BOD), Chemical Oxygen Demand (COD), phosphates, fecal coliform, and total coliform (BLH Provinsi Daerah Istimewa Yogyakarta, 2012).

As Gajahwong River is used for the sources of raw water and irrigation water, the aims of this research are to find out relationship between the river discharge and water pollution parameters. From the outcome, the water pollution control in order to achieve the benefits of sustainable water resources is recommended.

\section{WATER QUALITY AND QUANTITY CONTROL}

\subsection{Mock Model}

One of the rainfall-runoff models that are relatively simple and has been developed in Indonesia is a Mock model (1973). It can predict the discharge, especially for a sufficiently long time interval as a bi-weekly or monthly. To provide optimal simulation result, automatic optimization of the model parameters needs to be done (Damanjaya, et al., 1998).

\subsection{Pollution}

Pollution of the environment according to Law No.32 of 2009 is entered or the inclusion of living things, matter, energy, and/or other components of the environment by human activities that exceed the environmental quality standards that have been established (Kementerian Negara Lingkungan Hidup, 2003).

a) Water quality indicator used in analysis such as parameters of physics, chemistry, and biology. Indicators that water has been polluted are signs which can be observed and classified as follows (Effendi, 2003): Physical observation water pollution based on the level of water clarity (turbidity), temperature changes, color changes, smell changes, and taste changes. 
b) Chemical observation based on chemical contamination of solubility and $\mathrm{pH}$ changes.

c) Biological observation based on the water contamination of microorganisms in the water, especially the presence bacterial pathogens or not.

Indicators commonly used in water pollution are the $\mathrm{pH}$, dissolved oxygen (DO), biochemical oxygen demand (BOD), and chemical oxygen demand (COD).

\subsection{Water Quantity}

Measured flow data is rarely available, while the rainfall record relatively longer, so rainfall-runoff relationship is required. Mock (1973) in Harimawan (2003) has introduced a model for the rainfall-runoff that was applied in Indonesia. The model has relatively simple calculation method and easy to be applied. The calculation is performed based on the data of rainfall, evaporation, and hydrological characteristics of the study area. The Mock model can generate the availability of water in the watershed.

Water quality status describes whether a water source is polluted or not within a certain time by comparing to the water quality standards set. It was presented in the Decree of the Minister of Environment No.115 of 2003, guidelines for determination of water quality status, which is the Pollution Index method (Kementerian Negara Lingkungan Hidup, 2003).

Management of water quality based on this method can provide input to the decision-makers in order to assess the quality of water and improve the quality in case of loss due to the presence of polluting substances (Putro, 2014). The concentration of pollutant can be described by using Pollutant Index as follows:

$P I_{j}=\sqrt{\frac{\left(\frac{C_{i}}{L_{i j}}\right)_{M}^{2}+\left(\frac{C_{i}}{L_{i j}}\right)_{M}^{2}}{2}}$

with $C_{i}$ as concentration of water quality parameters (i) obtained from analysis, $L_{i j}$ as concentration of water quality parameters based on quality standard; $\left(C_{i} / L_{i j}\right) \mathrm{M}$ as maximum concentration parameters; $\left(C_{i} / L_{i j}\right) R$ as average concentration parameters. If $0 \leq$
$P I_{j} \leq 1.0$ then it meet quality standard; $1.0<P I_{j} \leq 5.0$ lightly polluted; $5.0<P I_{j} \leq 10.0$ moderately polluted; and if $P I_{j}>10.0$ heavily polluted.

\section{RESEARCH METHOD}

\subsection{Study Site}

The research location is in Gajahwong watershed, which has a drainage area of approximately $38.3 \mathrm{~km}^{2}$ as shown in the following Figure 2.

\subsection{Data Collection}

The data used in this research is secondary data such as rainfall, climatology, discharge, and water quality obtained from related institutions, thesis (Putro, 2014), and reports related to the research.

\subsection{Water Quantity Analysis}

Watershed map and rainfall data are used to derive the mean rainfall watershed using Thiessen Polygon method. The length of rainfall data used in this study is 12 years, ranging from 2001 to 2012 , which is derived from several rainfall stations around Gajahwong watershed. Evapotranspiration is calculated using the Penman Monteith method by analyzing the factors climatology from climatological stations around Gajahwong watershed ranging from 2001 to 2012. Then calculated discharge obtained from changing rain into streams with Mock method, given the input of mean rainfall watershed and evapotranspiration. Reliable discharge obtained from the graphical method of flow duration curve. The length of the measured flow data is ranging from 2002 to 2005 .

\subsection{Analysis of Water Quality}

The analysis of the physics, chemistry, and biology parameters was conducted to determine how much these parameters affect the water pollution in the watershed. Water quality data obtained during 2007 to 2012 on 8 observation points from upstream to downstream. Determination of the status of water quality was analyzed with Pollution Index method to determine water quality conditions, whether contaminated or not. 


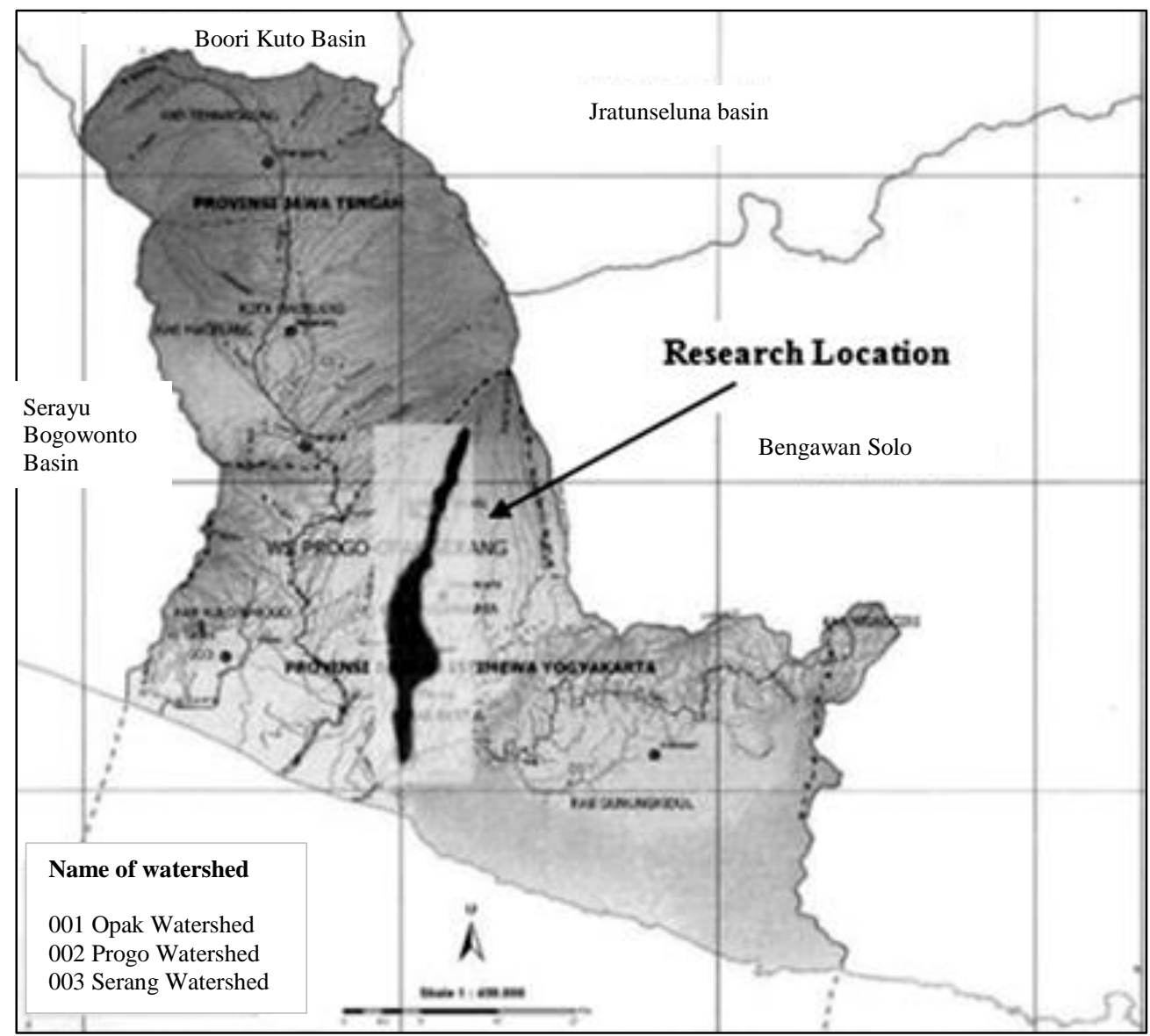

Figure 1.Research location.

\section{RESULT AND DISCUSSION}

\subsection{Water Quantity Analysis}

Through the calibration (October 2003 until September 2004) and verification (October 2004 to September 2005) processes by using Mock model, rainfall-runoff simulation was done as the following Figure 2.

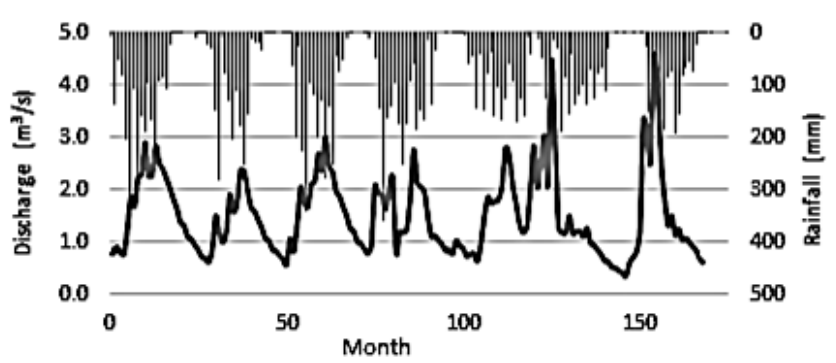

Figure 2.Mock model simulation result Gajahwong Watershed in Wonokromo.

Based on the simulated runoff, dependable flow in the form of low duration curve of Gajahwong catchment at Wonokromo station is given in Figure 3. The figure shows that $20 \%$ of the time, the discharge flow is less than $0.8 \mathrm{~m}^{3} / \mathrm{s}$. It means that the river flow has a potential to be polluted due to high pollutant from the entire catchment.

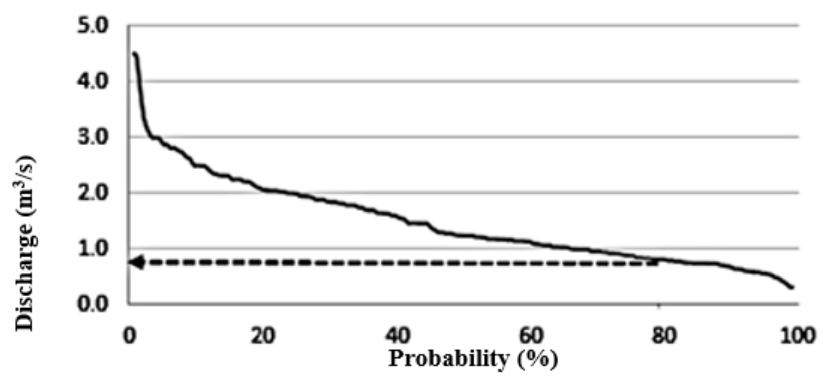

Figure 3.Flow duration curve of Gajahwong catchment at Wonokromo.

\subsection{Water Quality Analysis}

Water quality parameters in physics, chemistry, and biology were analyzed by using available data and characteristics of the pollutant source. The location of the water quality data from upstream to downstream areas can be seen in Figure 4, whereas the water quality parameters are depicted in 5 to Figure 10. 


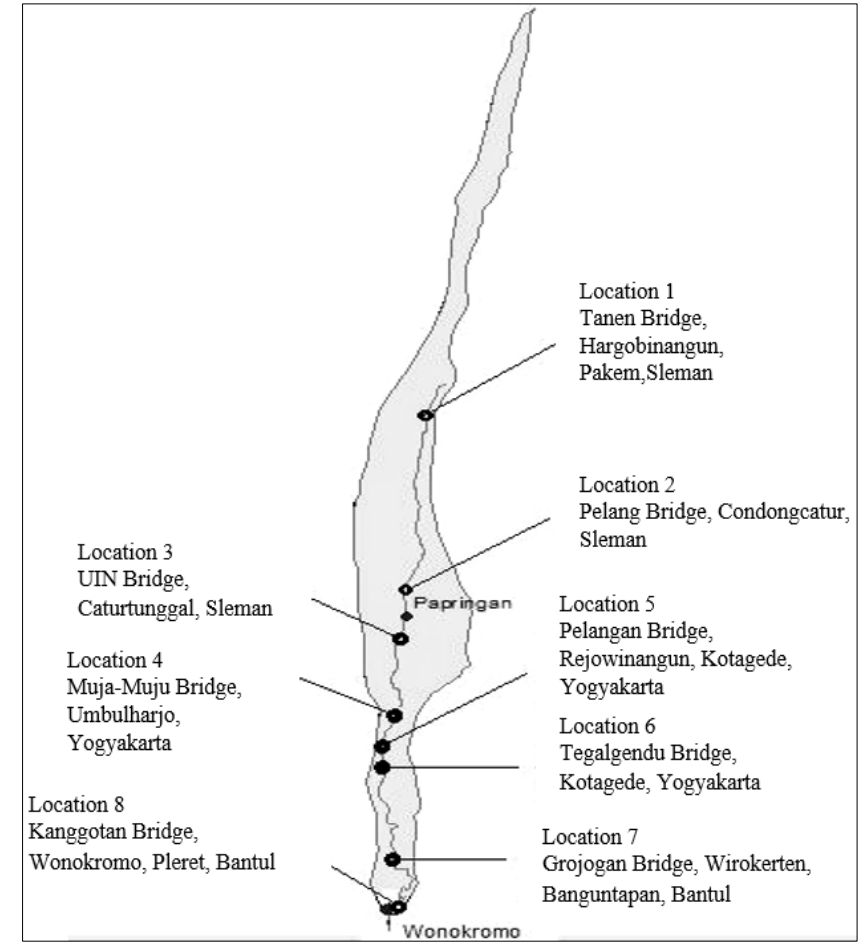

Figure 4. Location data acquisition.

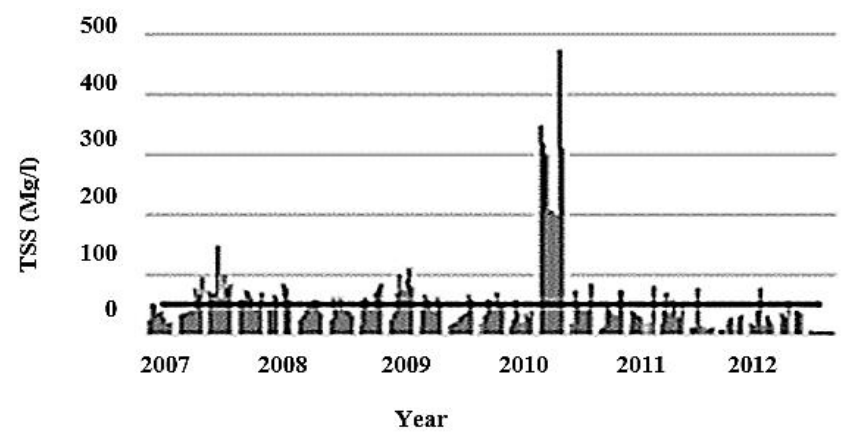

Figure 5. Level of water quality parameters of Gajahwong catchment from 2007 to 2012 (TSS)

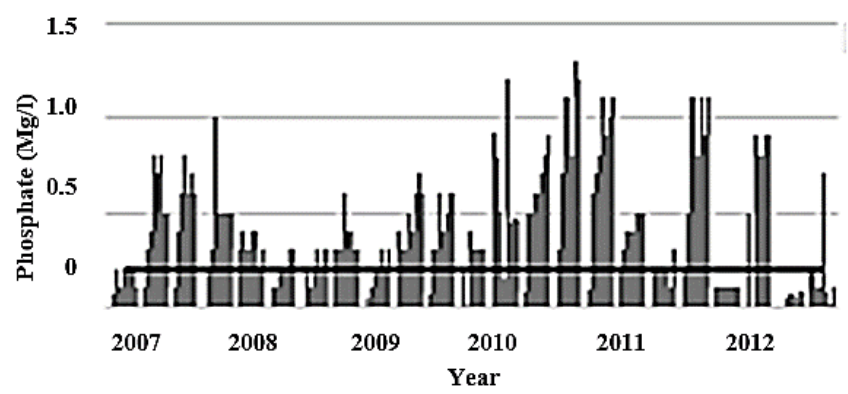

Figure 6. Level of water quality parameters of Gajahwong catchment from 2007 to 2012 (Phosphate)

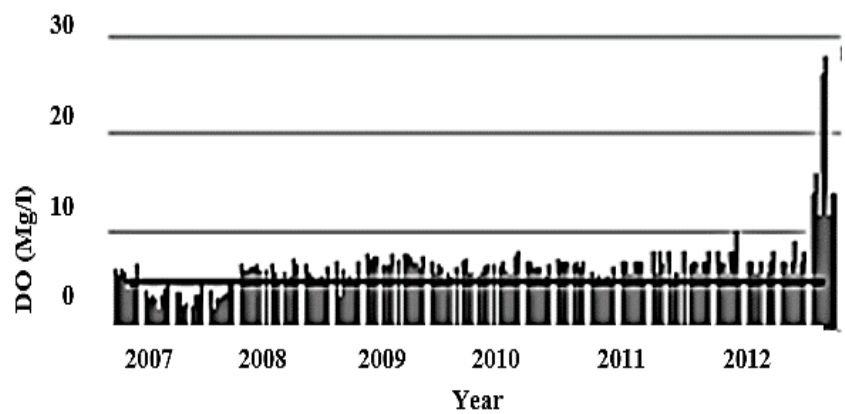

Figure 7.The level of water quality parameters of Gajahwong catchment from 2007 to 2012 (DO).

100

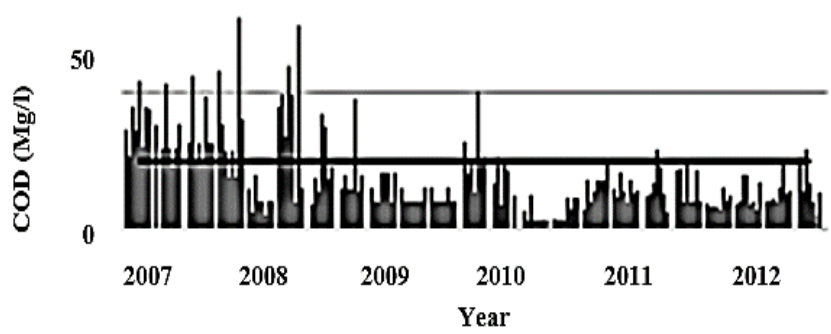

Figure 8. Level of water quality parameters of Gajahwong catchment from 2007 to 2012 (COD)

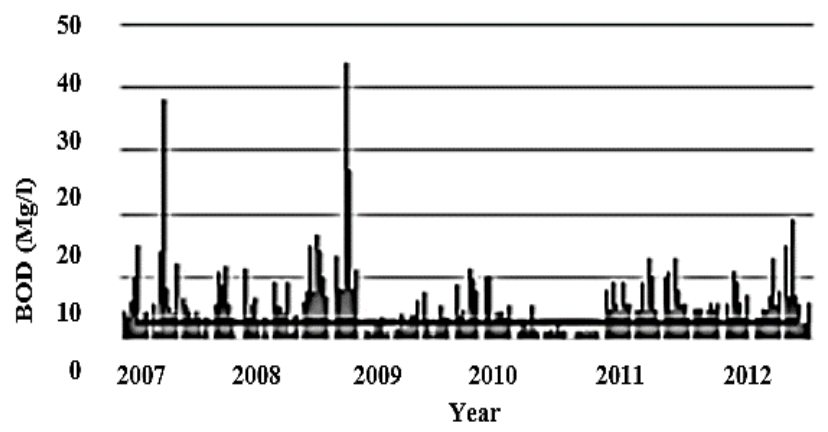

Figure 9. Level of water quality parameters of Gajahwong catchment from 2007 to 2012 (BOD)

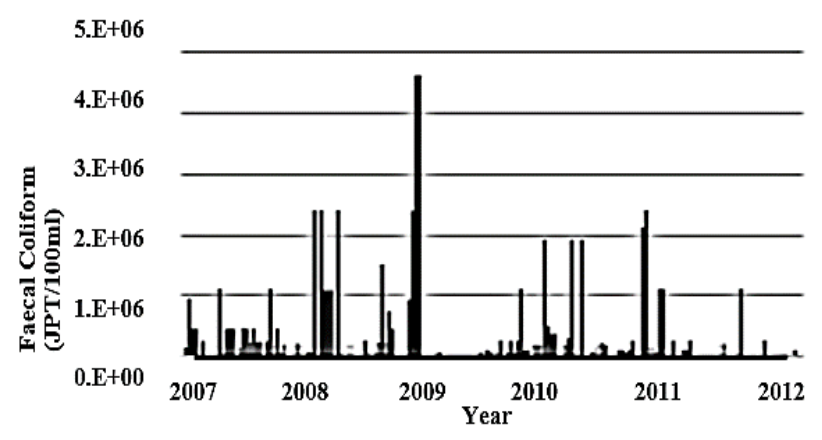

Figure 10 . The level of water quality parameters of Gajahwong catchment from 2007 to 2012 (Faecal Coliform). 


\subsection{Pollutant Index}

Pollutant Index value in the upstream ranged from 2.9 to 12.98 while at the central area ranged from 2.96 to 13.98, as well as in downstream ranged from 3.82 to 13.9. These values suggest that Gajahwong River being classified as moderately polluted as given in Figure 11.

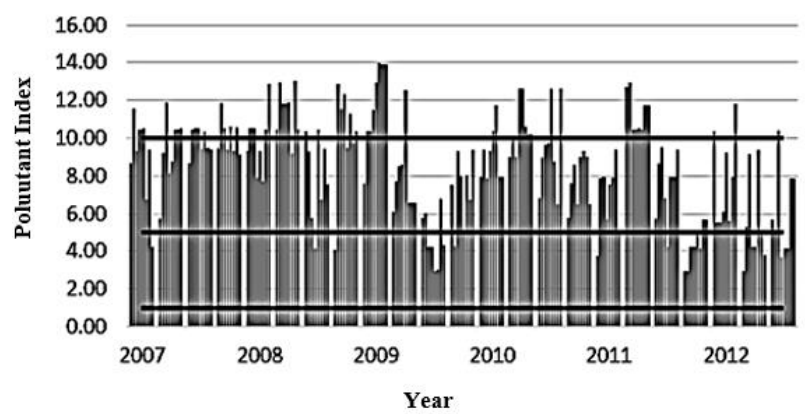

Figure 11. Gajahwong catchment Pollutant Index for 20072012.

\section{CONCLUSIONS}

Based on the study, it can be concluded that

a) Dependable flow $80 \%$ of Gajahwong watershed resulted from flow duration curve at Wonokromo is $0.747 \mathrm{~m}^{3} / \mathrm{s}$.

b) For the period from 2007 to 2012 the level of TDS, TSS, DO, COD, detergents, oils and fats, and fecal Coliform has decreased, whereas BOD, phosphate, and total coliform has increased. These conditions indicated that the water has been polluted. The concentration of the pollutants exceeds the threshold for water quality standards class II according to Governor Regulation Yogyakarta Provincial No. 20 of 2008. c) Water quality conditions at the Gajahwong River from upstream to downstream have been polluted with moderate level $(10 \leq \mathrm{IP} \leq 5)$.

\section{REFERENCES}

BLH Provinsi Daerah Istimewa Yogyakarta, 2012. Status Lingkungan Hidup Daerah Provinsi Daerah Istimewa Yogyakarata, Yogyakarta.

Damanjaya, D., Sujono, J. \& Nurrochmad, F., 1998. Optimasi Parameter Model Hujan-Aliran Mock dengan "Solver" [Optimization of Mock Rainfall Runoff Model using Solver]. Media Teknik, XX(2), pp. 58-62.

Effendi, H., 2003. Telaah Kualitas Air Bagi Pengelolaan Sumber Daya dan Lingkungan Perairan [Study on Water Quality of Water Resources Management and Environment], Yogyakarta: Kanisius.

Harimawan, A., 2003. Pembuatan Paket Program Aplikasi Analisis Hidrologi : Analisis Frekuensi, Model HSS GAMA I, Model HS GAMA II, dan Model Mock [Development of Application Program on Hydrology Analysis], Yogyakarta.

Kementerian Negara Lingkungan Hidup, 2003. Keputusan Menteri Lingkungan Hidup No. 115 Tahun 2003 tentang Penetapan Status Mutu Air, Jakarta.

Putro, S. S., 2014. Kajian Kuantitas dan Kualitas Air (Studi Kasus Gajahwong) [Analysis of Water Quality and Quantity of Water (Study Case of Gajahwong River)], Yogyakarta: Master Thesis, Department of Civil and Environmental Engineering, Universitas Gadjah Mada. 
[this page intentionally left blank] 